\title{
Concentration of Hydrogen Ions in Several Calcium Hydroxide Pastes over Different Periods of Time
}

\author{
Morgana Eli VIANNA ${ }^{1,2}$ \\ Danila M. ZILIO² \\ Caio Cezar Randi FERRAZ ${ }^{2}$ \\ Alexandre Augusto ZAIA ${ }^{2}$ \\ Francisco José de SOUZA-FILHO ${ }^{2}$ \\ Brenda Paula Figueiredo de Almeida GOMES² \\ ${ }^{1}$ Eastman Dental Institute, Unit of Endodontology, University College London, UCL, London, UK \\ ${ }^{2}$ Piracicaba Dental School, State University of Campinas, Piracicaba, SP, Brazil
}

\begin{abstract}
The purpose of this in vitro study was to measure the concentration of hydrogen ions $(\mathrm{pH})$ of calcium hydroxide $\left[\left(\mathrm{Ca}(\mathrm{OH})_{2}\right]\right.$ pastes combined with different vehicles over 7 periods of time. The $\mathrm{Ca}(\mathrm{OH})_{2}$ was manipulated with the following vehicles: i: sterile water; ii: iodoform plus sterile water; iii: local anesthetics (Lydocaine 2\% with 1: 100,000 epinephrine); iv: polyethyleneglycol; v: glycerin; vi: $2.0 \%$ chlorhexidine gel; vii: camphorated paramonochlorophenol (CMCP); viii: (CMCP) + glycerin; and ix: polyethyleneglycol plus CMCP. The pastes were made on a glass plate to toothpaste consistency and the $\mathrm{pH}$ was measured at the following times: 5 min, 1, 24, $48 \mathrm{~h} ; 7,14$ and 28 days. The data were statistically analyzed (Kruskal-Wallis at $\mathrm{p}<0.05$ ). At $5 \mathrm{~min}, 1 \mathrm{and} 24 \mathrm{~h}$, the pH of all tested pastes ranged from 13.05 to 11.16 . At $48 \mathrm{~h}$ and 7 days the $\mathrm{pH}$ of all tested pastes ranged from 11.66 to 8.92 . At 14 and 28 days almost all pastes had $\mathrm{pH}$ means lower than 10. In conclusion, the mean $\mathrm{pH}$ of all tested calcium hydroxide pastes decreased with the time. Pastes made with aqueous vehicles (especially with sterile water), followed by oily vehicles (especially with CMCP + glycerin), held the highest $\mathrm{pH}$ means over the periods of time tested.
\end{abstract}

Key Words: intracanal medication, calcium hydroxide, $\mathrm{pH}$.

\section{INTRODUCTION}

Calcium hydroxide has been recommended for use as intracanal medicament as it has pronounced antimicrobial activity against most of bacterial species found in root canal infections (1) and it also produces a neutralization effect in bacterial lipopolysaccharides (LPS) (2). Moreover, it has been mainly used to help to dry the persistently wet canal (3) and to reduce inflammation and pain (4). It also acts as a physical barrier to prevent the recontamination of the root canal (5), helps tissue dissolution and to prevent restraining osteocementum-dentin resorption, inducing tissue restoration through mineralization (6).

The efficiency of calcium hydroxide as an intracanal dressing is due to its ionic effect based on chemical dissociation into calcium and hydroxyl ions in aqueous solution $(1,3)$, which are responsible for alkalization of the medium, resulting in a $\mathrm{pH}$ greater than $11(4,7)$. Its high $\mathrm{pH}$ induces hard tissue formation through mineralization and is also responsible for its bactericidal effect. Alkalis in general have a pronounced destructive effect on cell membranes and protein structure (8).

The majority of the microorganisms grow better at $\mathrm{pH}$ around 7. An increase/decrease of this $\mathrm{pH}$ may cause reversible (temporary) enzymatic inactivation. Once the ideal $\mathrm{pH}$ is reestablished, the enzyme will again take up its catalytic activity. Although most microorganisms are destroyed at $\mathrm{pH} 9.5$, a few can survive at $\mathrm{pH} 11$ or higher (9). Therefore, to be effective against all microorganisms, $\mathrm{Ca}(\mathrm{OH}) 2$ should provide the environment with a minimum $\mathrm{pH}$ of 12.5 (1) as Enterococcus faecalis, a

Correspondence: Profa. Dra. Brenda Paula Figueiredo de Almeida Gomes, Departamento de Dentística Restauradora, Divisão Endodontia, Faculdade de Odontologia de Piracicaba, Universidade Estadual de Campinas, Avenida Limeira, 901, 13414-018 Piracicaba, SP, Brasil. Tel: +55-19-3412-5215. Fax:+55-19-3412-5218. e-mail: bpgomes@fop.unicamp.br 
resistant endodontic pathogen, can survive at $\mathrm{pH}$ 11.5.

Different enzymes have different ideal $\mathrm{pHs}$ for their reactions. Alkaline phosphatase, which is present in the tissues and is involved in the mineralization process, requires a $\mathrm{pH}$ around 8.6 to 10.3 to operate. Its optimum $\mathrm{pH}$ is 10.2 , which is consistent with that produced by many calcium hydroxide preparations (6). However, calcium hydroxide cannot be considered a universal intracanal medicament, as it is not equally effective against all microorganisms found in the root canal (5). Indeed, it has been reported the failure of $\mathrm{Ca}(\mathrm{OH})_{2}$ to eliminate enterococci effectively $(10,11)$ as they tolerate high $\mathrm{pH}$ values, varying from 9 to 11.5 .

A paste is considered chemically to be a colloid substance (a solid dispersed into a liquid). Therefore, the type of vehicle used may either facilitate or inhibit the ionic dispersion of the paste. Vehicles commonly used to prepare calcium hydroxide pastes are classified as aqueous, viscous, and oily.

Renewed interest has been generated regarding the association of calcium hydroxide with other antimicrobial substances $(10,11)$, such as camphorated paramonochlorophenol, chlorhexidine, iodine potassium iodide, and antibiotics.

Chlorhexidine has antimicrobial activity against Gram-negative and Gram-positive microorganisms. The antimicrobial effect of chlorhexidine is related to the cationic molecule binding to negatively charged bacterial cell walls, thereby altering the osmotic equilibrium of the cell. Its use in endodontics has been proposed as a chemical auxiliary substance and intracanal medicament $(5,10)$. When used as intracanal medicament, chlorhexidine was more effective than calcium hydroxide in eliminating E. faecalis (10). Considering that the $\mathrm{pH}$ values in the environment play an important role in the antimicrobial effect and tissue mineralization, the aim of this in vitro study was to measure the $\mathrm{pH}$ of various calcium hydroxide pastes using different vehicles over varying periods of time.

\section{MATERIAL AND METHODS}

The pastes were prepared in triplicate mixing calcium hydroxide (Labsynth, Produtos para Laboratórios Ltda, Diadema, SP, Brazil) with the following vehicles: Aqueous vehicles: i. sterile water (2:1); ii.local anesthetics (2:1; Lydocaine 2\% with 1: 100.000 epinephrine) (DFL, Indústria e Comércio Ltda. Rio de Janeiro, RJ,
Brazil); iii. sterile water plus iodoform (2:1:1) (Labsynth, Produtos para Laboratórios Ltda.); Viscous vehicles: iv. polyethyleneglycol (Calen; S.S. White, Artigos Dentários Ltda. Rio de Janeiro, RJ, Brazil); v. glycerin (2:1) (Chemco Indústria e Comércio Ltda, Campinas, SP, Brazil); vi. 2\% chlorhexidine gel (1:1); Oily vehicles: vii. camphorated paramonochlorophenol (2:1) (CMCP) (Biodinâmica, Química e Farmacêutica Ltda., Ibiporã, PR, Brazil); viii. CMCP plus glycerin (Chemco Industria e Comércio Ltda.) (Frank's paste 2:1:1); ix. CMCP plus polyethyleneglycol (Calen CMCP; S.S. White Artigos Dentários Ltda.).

The consistency of the pastes was similar to that of toothpaste, with a viscosity of $3501 \mathrm{cp}$. at $0.1 \mathrm{rpm}$ (Brookfield Digital Reometer, model DV-III-IV, São Paulo, SP, Brazil). The $2.0 \%$ chlorhexidine gluconate gel was manufactured by Essencial Farma (Itapetininga, SP, Brazil). Chlorhexidine gel consisted of chlorhexidine gluconate and a gel base named natrosol (1\%) which is a hydroxyethylcellulose and a water soluble substance. In addition to these groups the vehicles were also measured individually 3 times for the same time interval as described below.

The $\mathrm{pH}$ of the pastes was measured after the following times had elapsed: $5 \mathrm{~min} ; 1$, 24, $48 \mathrm{~h} ; 7,14$ and 28 days after manipulation using a pH meter (DIGIMED DM 21 V7c., São Paulo, SP, Brazil). For the first 7 days, the electrode was used for small portions (DME-CM1). From the eighth day on, it was necessary to use the surface electrode (DME-CV7), since the majority of the pastes, except for the pre-manufactured ones, became solid. The electrode was washed with ultrapure deionized water and wiped dry between readings. In order to eliminate environmental variables, all samples were stored in closed vials in a $37^{\circ} \mathrm{C}$ incubator until the time of measurements.

Sample adherence and normality were tested using the BioEstat program (CNpQ, 2000, Brasilia, DF, Brazil). The testes performed were in order to compare the $\mathrm{pH}$ values of each paste per period of time, using the Kruskall-Wallis and Dunn' test $(\alpha=0.05)$.

\section{RESULTS}

Table 1 shows the mean concentration of hydrogen ions ( $\mathrm{pHs}$ ) of several calcium hydroxide pastes for different periods of time. The standard deviations among replicates of the hydrogen ions were below $1 \%$. 
Overall, the mean $\mathrm{pHs}$ of all tested calcium hydroxide pastes decreased with the time. Analyzing the periods from $5 \mathrm{~min}$ to $24 \mathrm{~h}$, the calcium hydroxide pastes prepared with sterile water (i), local anaesthetic (ii), sterile water plus iodoform (iii), and CMCP plus glycerin (vii) showed $\mathrm{pH}$ values above 12 .

For the $48 \mathrm{~h}$ period, the calcium hydroxide combined with CMCP plus glycerin (viii) maintained its $\mathrm{pH}$ value close to 12 , while the calcium hydroxide pastes which local anesthetic (iii), polyethyleneglycol (Calen) (iv), glycerin (v), CMCP (vii) and Calen CMCP (ix) were used as vehicles showed $\mathrm{pH}$ values close to 11 . Interesting enough, the calcium hydroxide paste using $2 \%$ chlorhexidine gel as vehicle showed a $\mathrm{pH}$ value below $10(\mathrm{p}<0.05)$.

For the period of 7 days, the average $\mathrm{pH}$ value of all tested pastes ranged from 8.92 to 10.96 . The highest $\mathrm{pH}$ average value was 11.71 , obtained by the combination of CMCP plus glycerin (viii), the second highest value was obtained by the paste prepared with sterile water (I). Other pastes, such as local anesthetic (iii), polyethyleneglycol (Calen) (iv), glycerin (v), and CMCP (vii) also exhibited $\mathrm{pHs}$ close to 10 , showing no statistical differences from the pastes obtained by the mixture of CMCP plus glycerin (viii) and sterile water (i).

For the 14 day-period, the average $\mathrm{pH}$ values of all tested pastes ranged from 8.67 to 10.13 , being the Calen (iv) paste the only one that maintained its $\mathrm{pH}$ above 10 .

For the 28 day-period, the average $\mathrm{pH}$ values of all tested pastes ranged from 8.25 to 9.05 and Calen $\mathrm{CMCP}$ showed the highest $\mathrm{pH}$ (9.68) for this period.

Table 2 shows the mean $\mathrm{pH}$ values of all substances used as vehicles for several periods of time. The $\mathrm{pH}$ of the local anesthetics, which was acidic $(\mathrm{pH}=5.64$; $+0.197)$ for the first $5 \mathrm{~min}$, tended to be neutral $(6.5 \mathrm{pH})$ after 28 days. The vehicles classifieds as oily [CMCP, $\mathrm{CMCP}+$ glycerin and $\mathrm{CMCP}+$ polyethyleneglycol (Calen)] showed the highest $\mathrm{pH}$ values for all periods of time. Another important fact was that the CMCP totally evaporated after $48 \mathrm{~h}$, making its $\mathrm{pH}$ measurement impossible.

\section{DISCUSSION}

The antimicrobial and biological properties of calcium hydroxide pastes rely on its high concentration of hydrogen. In order to the calcium hydroxide pastes to be effective, the hydroxyl ions must diffuse into dentin and reach high levels to overcome the strong buffering capacity of dentine and to be lethal to the bacteria (9).

The type of vehicle used to prepare calcium hydroxide pastes promotes differences in the iondissociation velocity. These substances may influence the $\mathrm{pH}$ of the paste and thus influence both the velocity of ion diffusion through the dentinal tubules, and the dentin buffering capacity. Depending on the vehicle used, the medicament has different viscosity, which is a measurement of the inner friction of a fluid, in a manner

Table 1. Concentration of hydrogen ions (mean $\mathrm{pH}$ values) of several calcium hydroxide pastes over different periods of time.

\begin{tabular}{lccccccc}
\hline $\mathrm{Ca}(\mathrm{OH})_{2}$ combined with & $5 \mathrm{~min}$ & $1 \mathrm{~h}$ & $24 \mathrm{~h}$ & $48 \mathrm{~h}$ & 7 days & 14 days & 28 days \\
\hline Sterile water (i) & $13.05 \mathrm{a}$ & $12.94 \mathrm{a}$ & $12.18 \mathrm{ab}$ & $11.66 \mathrm{ab}$ & $10.96 \mathrm{ab}$ & $9.74 \mathrm{ab}$ & $9.05 \mathrm{ab}$ \\
Sterile water plus iodoform (ii) & $12.92 \mathrm{ab}$ & $12.74 \mathrm{a}$ & $12.07 \mathrm{ab}$ & $11.29 \mathrm{ab}$ & $9.73 \mathrm{~b}$ & $9.19 \mathrm{~b}$ & $8.73 \mathrm{ab}$ \\
Local anesthetic (iii) & $12.86 \mathrm{ab}$ & $12.88 \mathrm{a}$ & $12.10 \mathrm{ab}$ & $11.33 \mathrm{ab}$ & $10.72 \mathrm{ab}$ & $9.85 \mathrm{ab}$ & $8.83 \mathrm{ab}$ \\
Polyethyleneglycol (Calen) (iv) & $12.29 \mathrm{ab}$ & $11.97 \mathrm{ab}$ & $11.47 \mathrm{abc}$ & $10.92 \mathrm{abc}$ & $10.32 \mathrm{ab}$ & $10.13 \mathrm{a}$ & $9.58 \mathrm{a}$ \\
Glycerin (v) & $12.72 \mathrm{ab}$ & $12.05 \mathrm{ab}$ & $11.49 \mathrm{abc}$ & $11.11 \mathrm{abc}$ & $10.31 \mathrm{ab}$ & $9.45 \mathrm{ab}$ & $8.88 \mathrm{ab}$ \\
2\% chlorhexidine gel (vi) & $12.65 \mathrm{ab}$ & $12.44 \mathrm{ab}$ & $11.16 \mathrm{c}$ & $9.01 \mathrm{~b}$ & $8.92 \mathrm{~b}$ & $8.67 \mathrm{~b}$ & $8.25 \mathrm{~b}$ \\
CMCP (vii) & $12.50 \mathrm{ab}$ & $11.97 \mathrm{ab}$ & $11.67 \mathrm{ab}$ & $11.25 \mathrm{ab}$ & $9.82 \mathrm{ab}$ & $9.50 \mathrm{ab}$ & $9.49 \mathrm{ab}$ \\
CMCP plus glycerin (viii) & $12.80 \mathrm{ab}$ & $12.75 \mathrm{ab}$ & $12.68 \mathrm{a}$ & $12.25 \mathrm{a}$ & $11.71 \mathrm{a}$ & $9.62 \mathrm{ab}$ & $8.90 \mathrm{ab}$ \\
CMCP plus polyethyleneglycol & $12.30 \mathrm{c}$ & $11.83 \mathrm{~b}$ & $11.35 \mathrm{bc}$ & $10.74 \mathrm{ab}$ & $10.23 \mathrm{ab}$ & $9.63 \mathrm{ab}$ & $9.68 \mathrm{a}$ \\
(Calen CMCP) (ix) & & & & & &
\end{tabular}

Different letters indicate statistically significant differences in columns (Kruskal-Wallis and Dunn test; $\mathrm{p}<0.05$ ). 
that a solution flows easily when it has low viscosity. Therefore, the type of vehicle used may either facilitate or inhibit the ionic dispersion from the paste (4).

Overall, the concentration of hydrogen ions of all calcium hydroxide pastes decreased with time, contradicting the findings of Pacios et al. (12) and Yucel et al. (13). The first authors (12) evaluated the influence of different vehicles on the $\mathrm{pH}$ of calcium hydroxide pastes at $0,1,7,14$, and 21 days, and reported no significant difference in $\mathrm{pH}$ for different time intervals. The former authors (13) found significant differences in $\mathrm{pH}$ were observed among the pastes tested. Their results showed that the $\mathrm{pH}$ values of all experimental groups increased at 7 days. These differences among the present study and those mentioned are probably related to tested materials, evaluation times, and study design.

\section{Ionic Dispersion of Pastes Prepared with Aqueous Vehicles}

Pastes prepared with sterile water. In the present study, for the $5 \mathrm{~min}$ period, pastes prepared with sterile water obtained a mean $\mathrm{pH}$ of 13.05 . This value then decreased 12.94 after $1 \mathrm{~h}$. These values were higher than those found by other authors, which varied from 12 to $12 \cdot 6(1,3,10,14)$. This difference could be justified by the methods used, since the pastes in the present study were not placed in the root canal. It is known that the dentin can interfere in the effectiveness of calcium hydroxide, as demonstrated by Han et al. (9).
After $48 \mathrm{~h}$, all calcium hydroxide pastes showed mean $\mathrm{pH}$ values below 12, different from those values found by Estrela et al. (15), in whose work, the mean $\mathrm{pH}$ values stayed above 12 over the 60 days of experiment. The decrease of the $\mathrm{pH}$ in the present study with time may be due to the dehydrating process, since the pastes did not remain in a humid medium.

Teixeira et al. (16) investigated in vitro the dentin $\mathrm{pH}$ changes of the cervical, middle, and apical thirds of the root canals after 7 and 28 days. The authors showed that the $\mathrm{pH}$ values were higher in the cervical third than the apical third. When the paste was applied with lentulo spiral file, the apical $\mathrm{pH}$ was around 11.01 after 7 days, and around 10.7 in the same site after 28 days. These values were higher than the $\mathrm{pH}$ values obtained in the present study. This may be explained by the fact that Teixeira's samples were rinsed with sterile water prior the $\mathrm{pH}$ measurement.

In the present study a parallel experiment was carried out when the same paste constituent vehicle was added to those pastes that became hardened (i.e. sterile water-group $i$ and local anesthetic - group ii).The results demonstrated a rise of the $\mathrm{pH}$ at similar levels found in the first periods of the experiment (data not shown). This fact may be explained by the release of the ions by chemical dissociation in the presence of fluids (15).

In a clinical situation, one could speculate that when the canals are wet, such as in the presence of exudates, the environment may maintain the dissociation constant by the presence of fluid in contact with the paste.

Table 2. Concentration of hydrogen ions (mean $\mathrm{pH}$ values) of different vehicles over different periods of time.

\begin{tabular}{|c|c|c|c|c|c|c|c|}
\hline Vehicles & $5 \mathrm{~min}$ & $1 \mathrm{~h}$ & $24 \mathrm{~h}$ & $48 \mathrm{~h}$ & 7 days & 14 days & 28 days \\
\hline Sterile water & 8.28 & 7.75 & 7.47 & 7.27 & 7.13 & 6.96 & 6.93 \\
\hline Sterile water plus iodoform & 8.66 & 8.28 & 7.95 & 7.67 & 7.19 & 7.03 & 6.95 \\
\hline Local anesthetic & 5.64 & 5.72 & 5.83 & 6.11 & 6.45 & 6.64 & 6.59 \\
\hline Polyethyleneglycol & 8.22 & 8.01 & 7.88 & 7.71 & 7.64 & 7.57 & 7.27 \\
\hline Glycerin & 8.27 & 8.11 & 7.99 & 7.70 & 7.58 & 7.44 & 7.26 \\
\hline Natrosol & 8.76 & 8.49 & 7.96 & 7.19 & 6.80 & 6.52 & 6.37 \\
\hline CMCP & 9.38 & 8.97 & 8.41 & $* *$ & $* *$ & $* *$ & $* *$ \\
\hline $\mathrm{CMCP}$ plus glycerin & 9.90 & 9.83 & 9.67 & 9.29 & 8.94 & 8.19 & 7.90 \\
\hline CMCP plus polyethyleneglycol & 9.82 & 9.70 & 9.51 & 9.17 & 8.88 & 8.23 & 7.97 \\
\hline
\end{tabular}

**Vehicle volatilized. 
Pastes Prepared with sterile water and iodoform. Iodoform is universally added to calcium hydroxide in order to enhance the paste's radiopacity and consequently its observation after filling the root canal with the medication (7). The $\mathrm{pH}$ of this kind of paste was also evaluated in the present study, showing no statistically significant difference from the pastes with sterile water up to $48 \mathrm{~h}$ and also in 28 days period.

Pastes Prepared with local anesthetics. The $\mathrm{pH}$ of local anesthetics was measured after $5 \mathrm{~min}, 1,24,48 \mathrm{~h}$, 7,14 , and 28 days. It was noticed that its $\mathrm{pH}$ is slightly acid in the initial periods with a trend to neutral within the time (Table 2). Even though local anesthetics are acid, the $\mathrm{pH}$ of the calcium hydroxide pastes maintained alkaline, probably due to the small amount of the vehicle used. Moreover, the addition of calcium hydroxide to obtain the ideal paste consistence saturates the solution (13). In addition, the concentration of available hydrogen ions may be not enough to make any appreciable difference in the $\mathrm{pH}$ of the calcium hydroxide pastes. This may explain the reason for the high $\mathrm{pH}$ (approximately 12) achieved for the first $1 \mathrm{~h}$ period in the present study, agreeing with the finding of Fuss et al. (17). However, when different substance ratio is applied to obtain the pastes, the concentration of hydrogen ions may vary, as shown in one of the studies of Estrela et al. (15), who found a $\mathrm{pH}$ around 7.85 by mixing calcium hydroxide with local anesthetics.

\section{Ionic Dispersion of Pastes Prepared with Viscous Vehicles}

Pastes containing only polyethyleneglycol as a vehicle. The proprietary brand used in this study (Calen) has in its composition polyethyleneglycol as a vehicle. For almost all the periods tested, this paste showed lower mean values of hydrogen ions. This also happened with the proprietary brand that combined polyethyleneglycol with CMCP (Calen CMCP). A possible explanation of these results is that those commercial products contain other components in the paste's formulation, such as hydrogen colophony and zinc oxide and these substances may interfere in the release of the ions (9).

Pastes prepared with glycerin. Although the placement of pastes containing glycerin in the root canal is easier, it has been demonstrated that the calcium hydroxide mixed with glycerin reduces the conductivity of $\mathrm{Ca}(\mathrm{OH})_{2}$ solutions, suggesting that it does not dis- sociate completely. Consequently, this may decrease the effectiveness of calcium hydroxide as a root canal dressing. However, in this study, the mean $\mathrm{pHs}$ of the calcium hydroxide pastes prepared with glycerin, for all times tested, were not statistically different from those pastes made with aqueous vehicles.

Pastes prepared with $2 \%$ chlorhexidine gel. The aim of the association of calcium hydroxide and $2 \%$ chlorhexidine gel is to add antimicrobial properties to calcium hydroxide paste (10). In the present research, such a combination showed $\mathrm{pH}$ means lower than the pastes made with sterile water. However, it is important to note that the chlorhexidine antimicrobial property does not depend on the $\mathrm{pH}$, but is related to the cationic molecule binding to negatively-charged bacterial cell walls, thereby altering the osmotic equilibrium of the cell.

\section{Ionic Dispersion of Pastes Prepared with Oily Vehicles}

Pastes containing CMCP in the formulation. CMCP when used solely is volatile (Table 2). Chemically, it has been shown that its combination to calcium hydroxide yields calcium p-chlorophenolate, a weak salt solution. In a solution in water, the salt takes up the $\mathrm{H}^{+}$ ion and reconverts to p-chlorophenol, which gives off the excess of $\mathrm{OH}^{-}$ion from the water, thus maintaining the high $\mathrm{pH}$ (18).

According to Spångberg (19), this formulation prolongs the antimicrobial action because of the progressive release of $\mathrm{p}$-chlorophenol from the calcium $\mathrm{p}$ chlorophenolate compound. The antimicrobial property of the pastes containing CMCP and its high $\mathrm{pH}$ were the main reasons for treating non-vital teeth with wide-open apexes (20). It has been previously tested in one of our studies (11), where it was possible to verify that CMCP has a high antimicrobial activity against facultative and strictly anaerobic microorganisms, producing larger zones of microbial growth inhibition.

Fuss et al. (17) reported that pastes prepared with CMCP usually became hard, making their removal from the root canal difficult. This fact was also observed in the present study. Fourteen days after manipulation, the majority of the pastes, except those with polyethyleneglycol, with or without CMCP, became solid. Due to this fact, the use of the surface electrode was required, which was capable of measuring in water-scarce conditions.

Although the present study showed that the paste containing CMCP and glycerin (viii) reached the high- 
est mean $\mathrm{pH}$ up to the 7th day, its clinical use should be avoided, because CMCP is a known tissue irritant. Moreover, in this study, the $\mathrm{pH}$ of the paste containing $\mathrm{CMCP}$ in its formulation did not exhibit statistically significant differences, in most of the periods observed, from the pastes that used sterile water as a vehicle.

\section{Pastes Mixed with Different Vehicles and their Clini- cal Implications.}

Aqueous vehicles have rapid dissociation (4), achieving high values of $\mathrm{pH}$ in the initial periods, as observed in our results. Pastes prepared with sterile water kept the $\mathrm{pH}$ higher throughout the experimental period, agreeing with the findings of Yugel et al. (13) and Spångberg (19), who state that the best vehicle for calcium hydroxide is an aqueous solution, especially sterile water.

An aqueous vehicle rapidly dissociates calcium hydroxide into $\mathrm{Ca}^{++}$and $\mathrm{OH}^{-}$, promoting a high degree of solubility when in contact with tissue and fluids, denaturating proinflammatory cytokines and neuropeptides. Therefore, aqueous vehicles seems to be the most appropriated one to be used in the presence of continuous exudation or just after dental reimplant, due to the need for rapid ionic release and $\mathrm{pH}$ turnover to avoid replacement resorption. However, due to its rapid dissociation, it seems important to replace this medication in a short period of time (e.g. 7 days).

Some viscous vehicles, such as glycerin, polyethyleneglycol, propylene glycol and natrosol are also water soluble, but dissociate more slowly, probably because of their high molecular weight. The high molecular weight of these vehicles minimizes the dispersion of calcium hydroxide into the tissues and maintains the paste in the desired area for longer intervals. This factor prolongs the action of the paste, and $\mathrm{Ca}^{2+}$ and $\mathrm{OH}^{-}$ions will be given off at a lower velocity. It is via this mechanism that these pastes remain in direct contact with vital tissues for extended time intervals (4).

Therefore, such pastes should be used preferably when there is no more continuous exudation through the apex, meaning that the inflammation is under control, and also during the following periodical re-dressings of re-implanted teeth, because the paste may remain in the root canal for longer periods. A viscous vehiclecontaining paste may remain within the root canal for the interval of 2 to 4 months and the alkaline proper- ties of calcium hydroxide in such a paste will only be exhausted after a long period (4). During this time, the $\mathrm{pH}$ theoretically may be maintained in the area and a slow ionic release will occur; however further studies to evaluate if the concentration of hydrogen ions maintain in desirable levels are needed. Furthermore, a permanent restoration might be necessary in order to avoid coronal microleakage.

Oily vehicles are non-water-soluble substances that promote the lowest solubility and diffusion of the paste within the tissues. Pastes containing this type of vehicle may remain within the root canal for longer than the pastes containing aqueous or viscous vehicles. Oily vehicles contain little water and provide for little hydrolysis.

Some examples of oily vehicles are olive oil, silicone oil, camphor (the essential oil of camphorated paramonochlorophenol), metacresylacetate and some fatty acids such as oleic, linoleic and isostearic acids (4). Without sufficient water available, camphorated paramonochlorophenol forms calcium parachlorphenolate, thus preventing further hydrolysis (19). For this reason, pastes containing oily vehicles have restricted use and are only employed when those clinical situation require a very slow ionic dissociation. It is wise to observe that although in the present study, pastes manipulated with $\mathrm{CMCP}$ held higher $\mathrm{pH}$ averages during all the different periods of time evaluated, such substance may be highly irritant to the periapical tissues (19).

The high $\mathrm{pH}$ of calcium hydroxide has a destructive effect on bacteria cell membranes and protein structure (15), and also a $\mathrm{pH}$ value between 8 and 10 induces tissues mineralization. However, the use of calcium hydroxide pastes based solely on their initial high $\mathrm{pH}$ might not be effective against all microorganisms found in the root canal, as the $\mathrm{pH}$ can drop to 8 in 28 days if not moistened.

Finally, independently of the calcium hydroxide formulation, it should ideally occupy all of the pulp space to act effectively as an intracanal medicament (5), especially in the apical areas where the main dissociation is desired. In addition, the use of a permanent restoration might be necessary in long-time dressings, in order to avoid coronal microleakage (5).

On the basis of the results obtained and the experimental conditions used in this study, the concentration of hydrogen ions of all calcium hydroxide pastes decreased with the time. Pastes prepared with aqueous 
vehicles, especially with sterile water maintained the higher concentrations of hydrogen ions during the periods of time evaluated.

\section{ACKNOWLEDGEMENTS}

We would like to thank, Fernanda Barrichello Tosello, Thais Mageste Duque and Geovania Caldas Almeida for technical support. This work was supported by the Brazilian agencies FAPESP (07/58518-4; 08/58299-3), CNPq (305437/2006-2; 470820/2006$3,471631 / 2008-6)$ and PRODOC (0118/05-2).

\section{RESUMO}

O objetivo deste estudo in vitro foi mensurar a concentração de ions hidroxila $(\mathrm{pH})$ de pastas de hidróxido de cálcio manipuladas com diversos veículos em 7 intervalos de tempo. As pastas foram manipuladas com os seguintes veículos: (i) água destilada estéril; (ii) idodofórmio + água destilada estéril; (iii) anestésico local (Lidocaína a 2\% com 1:100.000 epinefrina); (iv) polietilenoglicol (Calen); (v) glicerina; (vi) clorexidina gel 2\%; (vii) paramonoclorofenol canforado (PMCC); (viii) PMCC + glicerina; e (ix) PMCC + polietilenoglicol (Calen PMCC). As pastas foram manipuladas em consistência de pasta de dente e os pH mensurados 5 min; 1, 24, 48 h; 7, 14 e 28 dias após manipulação. Os resultados foram analisados estatisticamente através do teste Kruskal-Wallis $(\mathrm{p}<0,05)$. Aos 5 min, 1 e 2 h após manipulação o pH de todas as pastas ficou entre 13.05 e 11.16 . Aos 48 h e 7 dias após a manipulação, o pH de todas as pastas testadas variou de 11.66 a 8.92 . Aos 14 e 28 dias, quase todas as pastas mostraram $\mathrm{pH}$ menor que 10 . Concluiu-se que o $\mathrm{pH}$ de todas as pastas hidróxido de cálcio decresceram de acordo com o tempo. Pastas feitas com veículos aquosos (especialmente com água destilada), seguida de veículos oleosos (especialmente com $\mathrm{CMCP}+$ glicerina) mantiveram as maiores médias de $\mathrm{pH}$ durante os períodos testados.

\section{REFERENCES}

1. Byström A, Claessom R, Sundqvist G. The antibacterial effect of camphorated paramonochlrophenol, camphorated phenol and calcium hydroxide in the treatment of infected root canal. Endod Dent Traumatol 1985;1:170-175.

2. Safavi KE, Nichols FC. Effect of calcium hydroxide on bacterial lipopolysaccharide. J Endod 1993;19:76-78.

3. Heithersay GS. Calcium hydroxide in treatment of pulpless teeth with associated pathology. J Brit Endod Soc 1975;8:74-98.

4. Fava LRG, Saunders WP. Calcium hydroxide pastes: classification and clinical indications. Int Endod J 1999;32:257-282.

5. Gomes BP, Sato E, Ferraz CC, Teixeira FB, Zaia AA, Souza-Filho
FJ. Evaluation of time required for recontamination of coronally sealed canals medicated with calcium hydroxide and chlorhexidine. Int Endod J 2003;36:60.

6. Tronstad L, Andreason JO, Hasselgren G, Kristerson L, Riis I. $\mathrm{pH}$ changes in dental tissue after root canal filling with calcium hydroxide. J Endod 1981;7:17-21.

7. Souza-Filho FJ, Soares Ade J, Vianna ME, Zaia AA, Ferraz CC, Gomes BP. Antimicrobial effect and $\mathrm{pH}$ of chlorhexidine gel and calcium hydroxide alone and associated with other materials. Braz Dent J 2008;19:28-33.

8. Gordon TM, Ranly DM, Boyan BD. The effects of calcium hydroxide on bovine pulp tissue: variations in $\mathrm{pH}$ and calcium concentration. J Endod 1985;11:156-160.

9. Han GY, Park S-H, Yoon TC. Antimicrobial activity of $\mathrm{Ca}(\mathrm{OH}) 2$ containing pastes with Enterococcus faecalis in vitro. J Endod 2001;27:328-332.

10. Gomes BP, Ferraz CC, Vianna ME, Sena NT, Zaia AA, Ferraz $\mathrm{CCR}$, et al.. In vitro evaluation of the antimicrobial activity of calcium hydroxide combined with chlorhexidine gel used as intracanal medicament. Oral Surg Oral Med Oral Pathol Oral Radiol Endod 2006;102:544-550.

11. Vianna ME, Gomes BP, Sena NT, Zaia AA, Ferraz CC, de Souza Filho FJ. In vitro evaluation of the susceptibility of endodontic pathogens to calcium hydroxide combined with different vehicles. Braz Dent J 2005;16:175-180.

12. Pacios MG, de la Casa ML, de Los Angeles Bulacio M, López ME. Calcium hydroxide's association with different vehicles: in vitro action on some dentinal components. Oral Surg Oral Med Oral Pathol Oral Radiol Endod 2003;96:96-101.

13. Yücel AC, Aksoy A, Ertaş E, Güvenç D. The pH changes of calcium hydroxide mixed with six different vehicles. Oral Surg Oral Med Oral Pathol Oral Radiol Endod 2007;10:712-717.

14. Staehle HJ, Pioch T, Hoope W. The alkalizing properties of calcium hydroxide compounds. Endod Dent Traumatol 1989;5:142157.

15. Estrela C, Sydney GB, Bammann LL, Felippe Jr O. Mechanism of action of calcium and hydroxyl ions of calcium hydroxide on tissue and bacteria. Braz Dent J 1995:6:85-90

16. Teixeira FN, Levin LG, Trope M. Investigation of $\mathrm{pH}$ at different dentinal sites after placement of calcium hydroxide dressing by two methods. Oral Surg Oral Med Oral Pathol Oral Radiol Endod 2005;99:511-516.

17. Fuss Z, Rafaeloff R, Tagger M, Szajkis S. Intracanal $\mathrm{pH}$ changes of calcium hydroxide pastes exposed to carbon dioxide in vitro. J Endod 1996;22:362-364.

18. Nerwich A, Figdor D, Messer HH. pH changes in root dentin over a 4-week period following root canal dressing with calcium hydroxide. J Endod 1993;19:302-306.

19. Spångberg LSW. Intracanal medication. In: Ingle JI \& Bakland LK, eds. Endodontics. 4th ed. Baltimore: Williams \& Wilkins, 1994 p.627-640.

20. Frank AL. Therapy for the divergent pulpless tooth by continued apical formation. JADA 1966;72:87-93.

Accepted October 8, 2009 